\author{
Душка Б. КЛИКОВАЦ* \\ Универзитет у Београду \\ Филолошки факултет
}

Оригинални научни рад

Примљен: 02.02.2020.

Прихваћен: 12.02.2020.

\title{
О УПОТРЕБИ ПРИЛОГА ТУ И О ПРИРОДИ СИСТЕМА ЗАМЕНИЧКИХ ПРИЛОГА ЗА МЕСТО У СРПСКОМ ЈЕЗИКУ ${ }^{* *}$
}

\begin{abstract}
У раду се, на теоријским основама когнитивне лингвистике, анализира употреба заменичког прилога $m y$. Утврђује се да њиме говорник може упућивати на место у близини саговорника (како се на основу његовог корена $m$ - и очекује и када је комплементаран прилозима овде и овамо), у својој близини (када је често заменљив прилозима овде и овамо), као и у њиховом заједничком простору, а може упућивати и анафорички - што је и његова најраспрострањенија и најразуђенија употреба. Од упућивања у физичком простору развија се упућивање и у апстрактним, метафоричким просторима. На основу анализе реконструише се одговарајући подсистем заменичких прилога за место у српском језику и закључује се да се он колеба између трочланог (и троличног): овде-ту-тамо (онде) одн. овамо - ту - тамо (онамо), и двочланог : овде/ту - тамо (онде) одн. овамо/ту - тамо (онамо) - што можда указује на даљи правац развоја система заменичких речи у српском језику. Анализа показује и да прилог ту може изгубити своју упућивачку функцију, кад му деиктички центар више нису учесници у комуникацији, и стећи природу прилога као што су близу, горе, напред и сл.
\end{abstract}

Кључне речи: савремени српски језик, когнитивна лингвистика, заменички прилози, прилог my, граматичка категорија лица, егзофора, анафора, појмовна метафора.

\section{1. Увод}

Иако су употребе заменичког прилога $m y$ обрађиване у научној литератури, његов положај у систему заменичких прилога за место није сасвим јасан. Пошто садржи корен $m$-, очекивало би се да упућује на место бли-

"klikovac@fil.bg.ac.rs

** Овај рад је настао у оквиру пројекта Српски језик и његови ресурси: теорија, опис и примене (бр. 178006), који финансира Министарство просвете, науке и технолошког развоја Републике Србије. 
зу саговорнику; а пошто не садржи ни суфикс -амо, који садрже заменички прилози који упућују на правац или место завршетка кретања (у даљем тексту: МЗК), нити -yд(a), који упућује на путању кретања, очекивало би се да упућује на место на којем се нешто налази одн. одвија (у даљем тексту: МН). У литератури је примећено да то није сасвим тако, али различити аутори имају различите налазе.

П. Пипер, у својој контрастивној студији о заменичким прилозима у српскохрватском, руском и пољском језику (Пипер 1988), закључује да ту може упућивати и на место близу говорнику и на место близу саговорнику (у ауторовој терминологији: има обележја и централности и периферности); прва употреба препознаје се у примеру - Где си била цеео дан? - Ту - одговара Бранка и седе поред носила, а друга у примеру Овде, у ходнику, је жена са дететом, а ту, у вашем купеу, има једно слободно место [...] (стр. 22); аутор такође закључује да ту обично упућује на МН (у ауторовој терминологији: има обележје локативности), али да може упућивати на МЗК (може имати и обележје адлативности).

Клајн (2005: 155) mу сматра прилогом који исказује МН (по ауторовој терминологији, „место у простору”), и то само у близини саговорника. Исто решење налазимо и у Нормативној граматици српског језика (Пипер/Клајн 22014: 202-203).

С. Кордић (2002: 93) сматра да ту може изражавати близину и 1. и 2. лицу, али само у значењу МН. У другом раду (Кордић 2003) прецизира да „[у] преко 95\% примјера my изражава статички аспект локализације”, али наводи и примере у којима ту упућује на МКЗ (,„изражава динамички аспект локализације ").

Најзад, Т. Ашић (2015) констатује да се „mу употребљава тамо где би се очекивало овде" (стр. 113), а сматра да разлика у значењу прилога овде, my и тамо „не може да се сведе на опозицију између области ја (говорника), ти (саговорника) и он (особе која је одсутна из комуникативне ситуације)" (стр. 112). ${ }^{1}$

Треба додати да се наведени извори, осим у тумачењу употреба прилога $m y$, некад разликују и по теоријским приступима и по исцрпности анализе. Највише података нуде С. Кордић (2003), која даје преглед најважнијих значења, али без претензија да објасни њихову међусобну везу, и Т. Ашић (2015, 2019), која бележи различита конкретна и апстрактна значења прилога $m y$, a његову употребу објашњава помоћу „тзв. фактора прагматичких инференција"; обе ауторке се нарочито баве разликом између прилога ту и овде.

У овом раду покушаћемо да детаљно, и на сразмерно обимном корпусу, анализирамо употребе прилога $m y$; при томе ћемо се служити појмовно-терминолошким апаратом когнитивне лингвистике (на нашем језику в. Кликовац 22006; Расулић 2004; Расулић/Кликовац 2014), који смо досад применили и на друге заменичке речи у српском језику (Кликовац 2010, 2013, 2016,

\footnotetext{
${ }^{1}$ Изворни рад је на енглеском језику, а у овом раду, из практичних разлога, наводимо превод (који је наш - Д. К.).
} 
2017, 2018 - у штампи). На основу резултата те анализе бићемо у прилици да нешто закључимо о природи система српских заменичких прилога за место у вези са граматичком категоријом лица.

Грађу за ово истраживање сачињавају следећа дела: Сумњиво лице Б. Нушића (скраћеница: Н.), Травничка хроника И. Андрића (А.), Људи говоре Р. Петровића (П.), Корени Д. Ћосића (Ћос.), Башта сљезове боје Б. Ћопића (Ћоп.) и Антологија народних приповедака (ур. М. Ђурић; скраћ.: Ант.), ${ }^{2}$ као и један текст из корпуса С. Савић и В. Половине (1989: 168-180; скраћ.: Разг.). Ексцерпирањем тих текстова добијено је око 500 примера употребе прилога $m y$. У обзир смо узели и примере из наведене стручне литературе, као и из Речника српскохрватскога књижевног језика (одсад: РМС) и Речника српскога језика (одсад: РСJ), један пример потиче из Корпуса савременог српског језика (www.korpus.matf.bg.ac.rs ; скраћ.: ЕК), а један смо забележили у говору.

\section{Ty као заменички прилог 2. лица: егзофора}

2.0. У складу са његовим кореном $m$-, заменичким прилогом $m y$ говорник (у даљем тексту: Г) може упућивати на место у близини саговорника (у даљем тексту: С). То место може бити у физичком простору (т. 2.1), али и у метафоричким просторима поседовања (т. 2.2) и намене (т. 2.3). У реченици може бити употребљена, осим ту, још нека заменичка реч 2. лица (пр. 1, 2).

Ty по правилу упућује на MH, а врло ретко на МЗК (таква су само два примера од укупно четрдесетак у овом значењу; један од њих дат је под бр. 5).

2.1.1. Место на које Г упућује прилогом ту може се налазити на С-овом телу (пр. 1) или близу С-а (пр. 2, 3). Из пр. 2 добро видимо да је ту у овом случају комплементарно са овде, а пр. 3 јасно показује да Г на исто место упућује и заменицом онај - ако је појам далеко од њега и од $\mathrm{C}$-а, и прилогом $m y$ - ако је на истом том растојању од њега али је близу С-a:

(1) Д[октор]: Показујеш ногу? Показујеш ногу, је л’? [...] Да, онда те је ту нога болела [...]? (Разг.) ${ }^{3}$

(2) ЈЕРОТИЈЕ (Милисаву): А јесу ли ту у фиоци списи што су нађени код онога?

МИЛИСАВ: Овде су.

ЈЕРОТИЈЕ: Добро их чувај [...]. А је л’ ти ту поверљиви протокол? (Н.)

(3) На то се аждаја насмеје, па јој рече: - Онде је моја снага у оном огњишту.

Онда баба притисне грлити и љубити огњиште, а аждаја, кад то види, [...] рече: - Луда жено, није ту моја снага. (Ант.)

\footnotetext{
${ }^{2}$ Сва ова дела, осим Травничке хронике, доступна су на сајту Учитељског факултета Универзитета у Београду (www.uf.bg.ac.rs).

${ }^{3}$ Прилог mу у примерима подвлачимо, а било који други елеменат реченице релевантан за анализу штампамо масним слогом.
} 
2.1.2. Г прилогом ту може упућивати и на место на којем се налази С. Предикат је тад у 2. лицу. Ty има чисто семантичку вредност (пр. 4, 5). Иста је употреба прилога $m y$ и у клаузи $m y$ си изговореној с узвичном интонацијом, која је на граници фразеологизма, јер има прагматичку функцију: служи Г-у да изрази изненађење (пр. 6).

(4) Стадоше пред сељаке. [...]

- Дођосмо - рече неко.

- Знао сам да сте ту - рече Аћим. (Ћос.)

(5) Кад нећеш звонити, што си ту дошао? (Ант.)

(6) Одмах краљ скочи с постеље па на таван, те Грбу за врат. Краљ се мало зачуди па рече: - Ту си, лопове, сад си ми запо̂ шака! [...] (Ант.)

Кад је предикат у облику императива, mу долази одмах иза њега. Тај прилог има и даље семантичку вредност - њиме Г упућује на место на којем се налази $\mathrm{C}$ - али и прагматичку: таквим исказом $\Gamma$ наређује $\mathrm{C}-\mathrm{y}$ да именовану радњу обавља на месту на којем се налази. Тиме имплицира да му је по статусу надређен, што исказу даје оштрину. Могућа су два случаја, у зависности од семантике глагола: императивом се исказује строга наредба (пр. 7) или се, ако С нема моћ над извршењем радње, исказује пре клетва него наредба (пр. 8).

(7) А ти ћути ту док ја не дођем [...]. - Никола устаде и поново га затрпа сеном. (Ћос.)

(8) Еро узјаше опет Турчина, те га још једном прејаше преко ћуприје, па га онда збаци Турчин на земљу: - Ето, цркни ту, кад немаш чим да платиш [...]. (Ант.)

У следећим примерима Г прилогом my упућује на место на којем се $\mathrm{C}$ налази (пр. 9), односно обавља неку радњу (пр. 10); предикат је у презенту. Са̂мо место је мање релевантно него радња која се ту обавља. Тако формулисан исказ је груб:

(9) КАПЕТАН: [...] (Спази практиканте.) А шта сте се ви, бре, ту искупили, као да је ово менажерија? (Шчепа дивите, лењире и све што му дође до руку и гађа их [...].) (Н.) ${ }^{4}$

(10) $[. .$.$] оде право пред царски двор и прислони се уз врата. Царски га$ ашчибаша спази [...], те га упита: - Шта ти ту чекаш? (Ант.)

Кад место уопште није релевантно за оно што С ради (тј. та радња би се могла обављати и на било ком другом месту), ту служи искључиво за исказивање прекора $(п р .11,12)$. Исти говорни чин се изводи и ако глагол стоји у конструкцији с немој (пр. 13):

\footnotetext{
${ }^{4}$ Пејоративност се у овом примеру изражава, осим прилогом $m y$, и на друге начине: реторским питањем, хиперболичним и пејоративним поређењем (као да је ово менажерија), речју бре, изрицањем личне заменице за друго лице. Ово последње средство је употребљено и у пр. 11.
} 
(11) А ти ту нешто мислиш да си бољи од њега. Ајде! (Ћоп.)

(12) КАПЕТАН: Е, видиш ли, синко голи, на шта изађе ствар? Заокупио ту: докуменат, закон, истрага, а оно ено шта испаде! (Н.)

(13) Ено га сад види. Ма немој ми ту кварити унука. (Ћоп.)

На крају, значење места у структури прилога ту сасвим је нестало, јер је реч о одсутном појму. Ту не лоцира ситуацију (и нема функцију одредбе места), него служи искључиво да искаже потцењивање (и везује се за именичку јединицу према чијем садржају Г има негативан став) (пр. 14). Исту вредност mу има и у споју овај ту: заменицом овај Г упућује на појам у својој близини, а прилогом ту исказује потцењивање, презир (пр. 15).

(14) Та неће ваљда ићи да загледа ђевојку - какоће дјед. - Још ћеш ту некаквој доконој парипини ићи угађати и табане му чешкати, а! (Ћоп.)

(15) [...] збуњеном интенданту тек наврх брдске косе коначно постаде јасно да умјесто краве води са собом голему доброћудну момчину. [...] - Шта ли ћу сад казати комесару? - хукну интендант. - Ко ће ми вјеровати да сам овога ту замијенио за марвинче? (Ћоп.)

2.2. У следећим примерима Г и С се налазе у истом односу према одређеном простору. Очекивало би се да Г одреди тај простор у односу на себе, тј. да употреби показну реч 1. лица; међутим, он употребљава прилог ту, којим имплицира да је то С-ов простор - а он може бити С-ов само у том погледу што му припада:

(16) ЈЕРОТИЈЕ (улази споља под капом): Је л’ није ту господин Вића? МИЛОСАВ: Није! (Н.)

(17) Кад дођоше у другу царевину, али крај бијелих дворова лијепа башта, врт [...]. Сад рече лија: - Ту је твој трс. (Ант.)

2.3. Г неки појам, који физички може бити подједнако удаљен и од њега и од $\mathrm{C}$-а, а може бити и ближе њему него C-y, фиктивно ставља у C-ов простор, да би му га наменио, наметнуо његовој пажњи, истакао да је то релевантно за њега и сл. Физички простор и простор намене обично се поклапају (оно што некоме намењујемо најчешће и стављамо у његов простор), али то није нужно случај: ${ }^{5}$

(18) Тетак Аћим пријекорно смаче раменима. - Шта има да се изражавам. Ево ти ту пјесника, то је његов посао. (Ћоп.) ${ }^{6}$

(19) - Медреса, медреса, упамти. То ти је ту, одмах на почетку алеје... дрвореда, она кућа с црвеним и жутим пругама. - Аха, она путаста, знам. (Ћоп.) ${ }^{7}$

\footnotetext{
${ }^{5}$ Чини нам се да се на такав начин може протумачити и пример Потпишите се $\underline{\text { my/oвde, }}$ молим вас, који даје Ашић (2015: 114): овде упућује на место у физичком простору Г-а, а $m y$ у простору намене С-у. На исти начин би се могао протумачити и пример Седи my негде (на било коју столииу која постоји у просторији) (пример даје Ашић 2015: 116).

${ }^{6}$ Показну речцу за прво лице - ево - Г је употребио зато што он нешто нуди (,,из свог простора"), а са ту намењује С-у то што нуди.

7 Значење прилога my појачано је и посесивним дативом $m u$. У примеру је јасно да је кућа подједнако, и сразмерно много, удаљена од обају саговорника (она путаста).
} 


\section{Ty као заменички прилог 2. лица: анафора}

3.0. Како је то и иначе случај са заменичким речима 2. лица, прилог ту не само што може бити употребљен анафорички него је таква употреба за њега типична (посведочена је у нашем корпусу више од три стотине пута, а и веома разграната). Он може упућивати на претходно поменути физички простор (т. 3.1), али и на различите метафоричке просторе (т. 3.2-3.9). У питању је чиста анафора (без егзофоричких примеса, коју уносе заменичке речи 3. лица).

Од укупног броја примера, у свега десетак mу упућује на МЗК (в. пр. $10,22)$.

3.1. Најчешћи антецедент је садржатељ. У питању може бити практично свака врста физичког садржатеља (в. Кликовац $\left.{ }^{2} 2006\right)$ : насељено место (пр. 1); просторија (пр. 2), зграда или институција (пр. 3); ограничен дводимензионални простор (пр. 4); предмет-садржатељ (пр. 5), укључујући и очи (пр. 6); део пејзажа (пр. 7); група/гомила (пр. 8). Антецедент је обично исказан, али се некад реконструише из контекста (у пр. 3 реконструише се његов предлошки део).

(1) Атијаси су најстарија јеврејска породица у Травнику. Ту живе већ преко сто и педесет година. (А.)

(2) Изнад ове дворане, на првом спрату, налазила се друга иста оволика, оскудније намештена, али светлија. Ту везир држи Диван само за време лета. (А.)

(3) Кад су стигли у Конзулат, Давна је замолио Давила да га прими на неколико минута и ту му је саопштио новости које је чуо из везирове околине. (А.)

(4) Кад је пролеће поодмакло и башта олистала, девојке су прешле у башту. Ту су везле преко целог лета. (А.)

(5) У том сандуку је Тахир-бегов дед затварао своје рукописе; отац му је ту чувао новац; а он, ево, држи лекове и завоје. (А.)

(6) Гледао је у њене очи, сјере и дубоке, са сјајем негде на дну, и учинило му се да и ту има неразумљивих обећања. (А.)

(7) [...] једнога дана нашао се с Даном у плиткој вртачи поред куће и ту су, под кржљавом лијеском, један другог обријали крњатком старе косе. (Ћоп.)

(8) Зато се све што је угрожено од непријатеља склања под окриље бригаде. Има ту чланова партијских комитета, омладинских и АФЖ-овских руководилаца, одборника, старих угледних људи [...]. (Ћоп.)

Антецедент може бити и носитељ - предмет са равном горњом површином (пр. 9), равна издигнута површина (пр. 10), равна површина на земљи (пр. 11), уопште површина (пр. 12), место (пр. 13): 
(9) - Ено, побратиме, видиш тамо на крају онај златни кревет, ту лежи царева кћи; сад отиди тамо, па зграби цареву кћер заједно с поплуном и брзо је донеси овамо. $(\text { Ант. })^{8}$

(10) На горњем спрату било је нешто више светлости, али је и ту [...] владала сенка пуна хладовине. (А.)

(11) Дуго ћу стајати на обали. Пре много година ту сам ја по младом леду прешао реку. (Ћос.)

(12) На зиду три слике. [...]. Ове слике висе ту већ више од половине људског века [...]. (А.)

(13) Претрнула, није могла да се макне с места и ту је дочекала Давила [...]. (A.)

Прилог ту може упућивати и на место исказано предлошко-падежном конструкцијом с предлозима код, поред, уз, крај, испред, пред, над, под, иза, између итд., или се ти предлози могу реконструисати (пр. 20):

(14) Поред тих прозора било је увек пријатно седети. Ту је увек било светлости и зеленила или бехара [...]. (А.)

(15) Идите ви, а мене чекајте код горе која плаче. Ту ћемо се наћи. (Ант.)

(16) $[. .$.$] па би се прибио уз огњиште, ријешен да ту проборави до суђе-$ на часа. (Ћоп.)

(17) Стража ће се пробудити, ухватиће те и одвести пред цара, и ту ће ти отићи глава доље. (Ант.)

(18) Други грађанин [...] сакрио се напред, иза рафа за фасцикуле и ту се шћућурио [...]. (Н.)

(19) То је та плочица између пршљенова, која хоће да се помери, па онда - па онда притиска живац [...] и онда се он ту укљешти - (Разг.)

(20) $[. .$.$] један од везирових коњаника одвојио се, као стрела појурио и$ брзо стигао Давила и његову пратњу, који су у том тренутку застали. Ту је нагло зауставио захукталог коња и гласно изговорио ове речи [...]. (А.)

Антецедент може бити исказан и зависном реченицом, кад је ту корелатив те реченице:

(21) Докле год досеже вриједна рука љетописца-млинописца, ту ти је угљеном записано ко све „тимари” кобилу или козу [...]. (Ћоп.)

(22) Наравно, тамо гдје су интенданти, ту је увијек близу и помисао на магацине, слагалишта и разноразну робу [...]. (Ћоп.) ${ }^{9}$

3.2. Ty може бити употребљено у приповедачком тексту, као текстуални конектор, са значењем „тада”, „у том тренутку”. Наиме, у приповедању се подразумева временска „линија”, на којој су поређани догађаји који чине основни приповедачки низ. Прилог ту упућује на „место” на тој „линији”,

\footnotetext{
${ }^{8}$ Тамо и овамо су, наравно, употребљени егзофорички.

${ }^{9}$ У овом примеру употребљен је корелатив и испред месне клаузе (тамо).
} 
одн. на догађај из тог приповедачког низа, за којим следи догађај који се прилогом ту најављује. У питању може бити место у развоју догађаја (пр. 23), у разговору (пр. 24), говору (пр. 25) или размишљању (пр. 26). ${ }^{10}$

Слично прилогу тад(а) (в. Кликовац 2017), ту уводи ситуацију која је изненадна и драматична, а може бити и завршна у низу:

(23) Сад је запита би ли му знала казати гдје живе Таригора и Кривигреда. Она му показа да су то њихови двори. Ту јој се он сад каже, узме је за руку па с њом у те дворе [...]. (Ант. $)^{11}$

(24) Убрзо после презривих речи о српском устанку као и о босанској војсци која треба да га угуши, разговор је сам од себе дошао на Селимову смрт. Ни ту се везир није изменио ни у гласу ни у лицу. (А.)

(25) [...] Хамди-бег застаде и у потпуној тишини одби један дим па настави:

- Па и да буде! Ваља видјети како ће бити и колико ће бити. Ничија није до зоре горила, па неће ни тога ... тога ...

И ту се Хамди-бег лако загрцну и закашља од прикривене љутње [...]. (A.)

(26) Јесте, човек зна да постоје ти јазови и све те противности међу људима [...]. Какве би то молитве требало да буду па да све то зајазе и изравнају? Њена потиштеност јој је одговарала да таквих молитава уопште нема. Али ту се њезина мисао, уплашена и немоћна, заустављала. (А.)

У тексту који није приповедачки, антецедент може бити и нека активност одн. догађање - појам који траје. Ту се опет може заменити прилогом maдa, али овог пута са значењем „током те активности/догађања” или, уопштеније, „том приликом":

(27) Ваља им опет прелазити ону јучерашњу цесту коју контролише непријатељ. Може ту доћи до густог. (Ћоп.)

(28) Жена удовица, попила она, попио ја, па шта ћеш, свакакве се ту работе десе - слеже Пантелија раменима. (Ћоп.) $)^{12}$

3.3. Антецедент прилога ту могу бити и околности, на основу метафоре (метонимијски засноване) околности су место. Овај случај се надовезује на претходну групу примера (пр. 28) - нека активност, догађање или стање ствари лако прерастају у околности у којима се нешто дешава:

(29) Сутрадан је био ручак на који су позвани Давил са женом и Дефосе. Осим њих ту су били долачки жупник фра Иво Јанковић и млади викар гучегорског манастира [...]. (А.)

\footnotetext{
${ }^{10}$ Кордић (2003: 89) такву употребу прилога mу назива метатекстуалном, кад он „има значење 'на том мјесту у говору / у писању / у приповиједању' и уводи неки метатекстуални додатак”. Ашић (2019: 68) бележи да је у том случају могуће употребити и овде, али не и тамо.

${ }^{11}$ На временско значење прилога ту указује и прилог сад; заправо, као да је значење прилога $m a \partial(a)$, који би по значењу одговарао датом контексту, разбијено за две компоненте: анафоричку компоненту (исказану прилогом $m y$ ) и временску (исказану прилогом $c a d$ ).

${ }^{12}$ Трајање је у овом примеру означено резултативним крњим перфектом.
} 
(30) Па се некако подеси и то да свака кућа прибави своју „фелу” најменика. Један домаћин увијек налети на свађалицу, па се ту поваздан ронда, богара и виле се потежу. (Ћоп.)

3.4. Антецедент је некакво циљано стање ствари или активност, а my значи „ради тога”, „да би се то догодило/обавило” (пр. 31) или „за то” (пр. 32) - или пак ,да се то не би догодило” (пр. 33):

(31) Шта је за сеоско момче био камарат у она [...] вучја времена, то се из чиста мира, тријезно, не да исказати. Ваљало би ту намакнути пред очи какво млако јесење вече у коме шушти презрео кукуруз, налијеже на рамена језеро згуснутих звијезда, а душу извлачи ојкава пјесма невидљивих дјевојака. (Ћоп.)

(32) - Па нек буде и тако, али дедер ти мене поучи како да ми њега излијечимо од те будалаштине? Жао ми, браћо, младице, начисто увену грешно чељадешце.

- Није ту лако лијека наћи - вајка се брадоња. - Мораш, просто-напросто, пустити да се рана сама смири и зацијели. (Ћоп.)

(33) Ја знам шта је теби тешко: теби је жао изгубити златну јабуку, али ја ћу ти и ту помоћи. (Ант.)

3.5. Ту има апстрактно значење „у вези с тим”; антецедент је неки појам или неко стање ствари:

(34) Све што је фра Лука у току година сакупио знања и података [...] било је садржано у тим свескама. Па и ту је фра Лука наилазио на неблагодарност своје браће и на многа разочарања. Једни су несавесно преписивали, други су из незнања или непажње кварили или испуштали поједине речи и читаве реченице [...]. (А.)

(35) Забушанти и докоњаци из команде позадине одавна су командиру „,реалне” пришили надимак Цар Душан [...]. Јашта него цар, шта ту има да се прича. (Ћоп.)

(36) Али кад се у некога усели зло, онда ту не помаже ништа. (Ант.)

$T y$ је употребљено у овом значењу и у оквиру израза нема ту (ни)шта, одн. нема ту, који може значити „нема у вези с тим шта да се разговара/дискутује" (пр. 37), али може прерасти и у поштапалицу, без јасног значења (пр. 38):

(37) Е, јеси прави Џакан, нема ту шта... (Ћоп.)

(38) Ја сам иш'о од куће. Нема ту. Попустило ме, шта ја знам, мало, и про’од’о сам / и каже докторица: „Добро, ти иди”. (Разг.)

У неким случајевима упућује на претходно поменуту ситуацију без јасне семантичке везе са следећом, која се, онда, мора реконструисати из контекста:

(39) - Већ је тај некуд здимио с кравом, не би га сад ни божија мајка нашла - јавну се Василије и саучеснички се осмијехну као да се ту о њему баш ништа не ради. (Ћопић) 
(40) Другога јутра нашли су пролазници Кукчево тијело на магленој прузи, и властима је успјело да утврде идентитет трупла тек послије необично дуге истраге. Да ли се ту радило о несретном случају или о самоубојству, није се могло установити никако. (Кордић 2003: 89) ${ }^{13}$

С. Кордић (2003: 89) каже да се „анафоричко my које упућује на ситуацију” користи и у изразу шта се ту може:

(41) „Посао је посао, Charles, што се ту може!”

3.6. Антецедент прилога my је писани текст или књига (текст је садржатељ за значење):

(42) А још истог дана, оба конзула су, у исто време, седели дуго над табацима грубе хартије за концепте и низали дуге редове службеног извештаја о првом виђењу са својим партнером. Ту је прва посета изгледала сасвим друкчије. (А.)

3.7. Антецеденти су различити апстрактни садржатељи: човеков емоционални простор (пр. 43), временски одсечак (који се метафорички концептуализује као ограничени дводимензионални простор - пр. 44), области знања (пр. 45) и сл.

(43) Од тога тренутка, тумач се, уплашен, повукао у себе и ту почео да меси своју мржњу на старешину, невиђено и потајно [...]. (А.)

(44) Сва своја искуства у свету, своје мисли [...], своје жеље и своја негодовања, Давил је пребацивао у далека времена и магловите прилике у којима је живео његов главни јунак, и ту им је пуштао слободна маха и настојао да их садеље у правилне стихове и вишемање строге риме. (А.)

(45) Потпуковник је био потпуно немузикалан [...]. Разговори о митологији и римским песницима ишли су много боље, али ту је опет Ана Марија била слабија и на сваки њен дистих овај необични потпуковник је одговарао низом стихова. (А.)

3.8. У овој групи примера рилог ту значи „у томе”, а у питању је таква употреба предлога $y$ која проистиче из метафоре иНТЕРПРЕТАЦИЈА НЕКОГ ЕНТИТЕТА ЈЕ ПРОНАЛАЖЕњЕ ОБЈЕКТА КОЈИ СЕ У ФЕМУ САДРЖИ (В. КЛИКОВаЦ ${ }^{2} 2006$ : 173-177). Антецедент је ентитет који се интерпретира, а сам појам интерпретације обухвата различите ствари: уочавање правог идентитета одн. особине неке појаве (пр. 46, 47), узрок појаве (пр. 48) или њену последицу (пр. 49). Глагол који је предикат клаузе којој припада прилог ту има егзистенцијално значење (обично је то имати или бити).

(46) КАПЕТАН (Вићи): Ама, читај кад ти кажем! Ко зна шта се ту крије, јер ти револуционари имају тако неке шифре, па једно пише а оно му друго значи. (Н.)

\footnotetext{
${ }^{13}$ С. Кордић тим примером илуструје случај кад $m y$ „упућује на читаву ситуацију описану у претходном контексту и може се парафразирати помоћу 'у тој ситуацији, у свему томе' и сл." (Кордић 2003: 89).
} 
(47) - А том истом руком сликаш и коње, a? - Сликам. - Па како то? - Лијепо, брате. Шта_ту има необичнога? (Ћоп.) [= „шта је ту необично"]

(48) Плаче он тако [...], а у томе дође к њему нека стара [...] бака, па га запита шта му је да тако плаче. А он јој одговори: - Па није ми - вели - ништа. Ето сјетио сам се своје покојне мајке, па ми се нешто ражалило и стешчало.

На то ће бака: - Ма знам, синко, знам, али има ту и још нешто. [...] Мој синко, ти плачеш зато што си гладан [...]. (Ант.)

(49) Одговори чобан: - Прометну ми се она шеница: све никоше букве и јеле.

Тада краљ рече: - Ox, ту би много штете!

А чобан прихвати: - Ту мене није штете, већ ми је корист. (Ант.)

3.9. Прилог my може бити анафорички употребљен и у оквиру израза бити ту негде, који може значити „отприлике тако као што је речено” или „слично томе”. Ty има значење „близу тога (што је речено)”, а негде уноси значење неодређености („отприлике”). Осим метафоре сличност ЈЕ БлизинА (пр. 50), У ПИТањУ може бИТИ И метафора НАГАЂАњЕ ЈЕ ТРАЖЕњЕ ОБЈЕКТА У ПРОСтору (пр. 51).

(50) Д[октор]: Да ли је сада боље и у односу на стање када си био тамо?

П[ацијент]: Пааа, ту је негде. (Разг.)

(51) - Удата си? - пита [жену] Синан ... Удовица? - вели Синан. - Ту си негдје. (РМС: Ћ. Сијарић)

\section{4. $T y$ као заменички прилог 1. лица}

4.0. Прилогом my Г може упућивати и на свој простор - физички (т. 4.1) и два метафоричка - простор времена (т. 4.2) и поређења (т. 4.3). У овој употреби ту може доживети и пуну адвербијализацију, кад постаје прилог као што су горе, доле, близу, лево, десно, напред итд.

4.1. Г прилогом my упућује на простор који му је сразмерно близу. Наиме, оно што је у том простору чулно му је доступно - надохват руке одн. при руци (пр. 1), пред очима (пр. 2), пред њим (пр. 3), у видном пољу (пр. 4), у близини (пр. 5), у кући (пр. 6), па и психолошки близу (пр. 7). ${ }^{14}$

$T y$ у управном говору може имати вредност прилога овде (пр. 1) и, као и све заменичке речи 1. лица, може имплицирати да је тачка гледишта Г-ова (пр. 2-7):

\footnotetext{
${ }^{14}$ Ово значење се имплицира у дефиницији лексеме овај која се у РСАНУ даје под т. 1.а: „који је овде, који је присутан, који се налази $m y$, у близини” (истицање курзивом наше - Д. К.). Наиме, ту и у близини употребљени су као синоними.
} 
(1) - Па гдје је, гдје је тај? - запита орлетица. - Ма гдје ми је, кажите ми? Ја бих га, да ми је ту, од радости и милоште, овај час појела! (Ант.)

(2) То кројење и прекрајање званичног извештаја у мислима умирило је мало Давила. Злочин који се десио колико јуче, ту пред његовим очима, изгледао је одједном мање страшан и одвратан [...]. (А.)

(3) А Давил је одједном осетио да је увређен и бескрајно више усамљен него што је био још пре неколико минута. Чинило му се да ту пред њим стоји слика и прилика новог нараштаја и да је прстом додирује. (А.)

(4) Видећи да фон Митерер гледа предмете на асури, и Давил сакупи снагу и баци поглед на разастрте трофеје. Мртви предмети од коже и метала били су двоструко мртви и лежали су ту, жалосни и напуштени [...]. (А.)

(5) Опет искрсну у њему оно јутрошње осећање запрепашћења да се ту у његовој близини и у вези са његовим радом, дакле и са њим, десио злочин [...]. (А.)

(6) Да је женско [...], истрпео би осамнаест година па би га удајом изјурио из куће. Али, мушко је рођено да заувек остане ту, у његовој кући, и пород запати. (Ћос.)

(7) Обућарски син, који је бежао из једног света и хватао место у другом, видео је у томе позиву знак судбине и добродошлу могућност да се и материјално удаљи од родитељске беде која је живела ту, свега неколико улица даље од њега. (А.)

Посебну пажњу заслужују следећи примери, јер у њима mу не упућује на место близу учесника̂ у комуникацији, него близу трећем лицу, и значи, просто, „близу”, дакле близу било коме. Прилог mу је, онда, изгубио своју упућивачку вредност и постао прилог као што су близу, горе, доле, напред и сл., који захтевају деиктички центар, али он може бити било која особа или објекат у простору:

(8) Каваз Хусеин, Арнаут, [...] заустављао се пред дућанима и што год би затражио, Турчин са ћепенка одговарао је, намрштен, да тога нема. Тражена роба је често висила ту, надохват руке, и кад би му каваз то приметио, дућанџија би или одговарао мирно да је то продано $[\ldots]$.

(9) Поткрај разговора лекар је постајао све тиши и све чуднији. Сео је и он, сасвим поред младића, сагнувши се према њему [...] и дајући му знак са обе руке да буде миран и да речима или покретом не поплаши и не одагна нешто ситно, драгоцено и плашљиво, као птицу која је ту, на поду, пред њима. Загледан у то место на ћилиму, говорио је готово шапатом [...]. (А.)

На исти начин заменички прилог ту је доживео пуну адвербијализацију и у изразу ту ми/joj/му/им... је, са значењем „имам/има... код себе” (пр. $10)$, с тим што „код себе” може метонимијски да прошири значење на „код 
себе кући”, тј. „на мом уобичајеном месту”, а одатле и „у гостима” (примере као што је 11 бележи Ашић (2015: 125-126), са другачијим објашњењем: да „субјекат у свом релевантном 'функционалном' месту има посетиоца”):

(10) Јел ти ту телефон? Ту му је телефон. (забележено у разговору)

(11) Ту ми је другарица. Шетамо.

4.2. Од упућивања у физичком простору развија се метафорички упућивање у простору времена. Г прилогом ту тада упућује на појам који се налази у временској близини, било да је то будућност (пр. 12) или прошлост (пр. 13):

(12) Лекари нађу да је стање болесника врло опасно и да је катастрофа ту, неизбежна за који дан. (РMC: Скерл.)

(13) Ама кажи ми, цркве ти, е смо се ту неки дан између нас на сијелу имали за длаку побити [...]. (Ант.)

Треба запазити да и у пр. 12 mу означава близину 3. лицу, а не учесницима у комуникацији.

Исту, временску употребу прилог ту има и у изразима ту скоро, mу недавно, ту неки дан и сл., које помиње $P M C$, са дефиницијом „за појачавање значења близине: пре кратког времена, недавно".

4.3. Ty може значити и „отприлике”. Реч је о близини у простору поређења (релевантна метафора је сличност ЈЕ ьлизинА). Ту је опет употребљено као прави, а не заменички прилог:

(14) Зато што, овај, ту смо на пола пута - (Разг. $)^{15}$

\section{Ty које упућује на простор заједнички говорнику и саговорнику}

Г прилогом ту може упућивати на место на којем се он налази заједно са С-ом. Да бисмо објаснили о чему је реч, употребићемо пример који наводи Кордић (2003) у вези с прилогом овде. Г са С-ом разговара телефоном и каже: Овог часа затварам и долазим к теби. Ја овдје више не остајем. Г, по нашем језичком осећању, није у том случају могао уместо овдје рећи ту; прилог my би могао бити употребљен само ако би био присутан и С: Ja $\underline{m y}$ више не остајем. ${ }^{16}$

Додатни доказ налазимо у пр. 1, где и Г и С употребљавају прилог ту да упуте на исто место; стога то може бити само заједничко место. ${ }^{17}$

\footnotetext{
${ }^{15}$ Т. Ашић (2019: 69) наводи пример Њих двојица су my по висини, где ту има значење „квантификативне проксималности".

${ }^{16}$ Исто важи и за два примера из телефонског разговора која наводи Ашић (2015: 117): Хоћеш mу да спаваш вечерас? и Хоћемо ту да вечерамо?. Ауторка сматра да се „ту може односити и на говорниково и на саговорниково место"; по нашем језичком осећању, међутим, ова друга инптерпретација је много вероватнија.

${ }^{17}$ У овом примеру прилог овамо упућује на исто место на које упућује и прилог ту. Дакле, оба саговорника су могла употребити и прилог овде уместо $m y$.
} 
Заједничко место на које Г упућује прилогом mу може бити место на којем се борави - просторија или зграда (пр. 1), или насељено место одн. земља (пр. 2, 3, 4).

(1) $[. .$.$] ето ти сунца, па, назвавши матери добар вече, рече јој:$

- Мајко, ту мирише рајска душица.

А мајка му одговори:

- Нема ту, синко, никога; та не може овамо ни тица долетети, а како би рајска душица дошла? (Ант.)

(2) [...] а ако немаш воље да идеш одавде [= из подземаљског света] можеш остати па ту живљети [...]. (Ант.)

(3) - Чујеш, Раде, па не мора то баш бити нека ту, домаћа Маријана. Бог зна због чега то човјек тугује, па кроз пјесму олакшава души. (Ћоп.) $)^{18}$

(4) У кафани, у којој раније није одседао, узео је собу „на дуже” и страховао да не сретне познаника, некога ко би га упитао за укућане и њихово здравље [...], запитао шта он ради сада ту, у Београду. (hoc.)

\section{6. Израз бити ту}

6.1. Израз бити ту значи „постојати на датом месту, у датим околностима, ситуацији”, „бити присутан” (ово друго значење региструје и Ашић 2015: 121). ${ }^{19}$ Значење прилога ту у оквиру тог израза могло се развити из значења које има кад је 1. лица или кад упућује на заједнички Г-ов и С-ов простор.

Фокус може бити на ту (пр. 1, 2, 3), али не мора (пр. 4, 5).

(1) Царица [...] скочи брже-боље и одведе га ђевојци у собу. Како га ђаво опази, он му проговори:

- Ту си, побратиме?

- Ту сам. (Ант.)

(2) Аћим ћути и гледа у колена. Нема црвених вунених рукавица, и очима топлих. [...] Да је Симка ту, грдио би је. (Ћос.)

(3) [C]ељаку се, бар за један свијетли тренутак, учини да би једном некуд вриједело отићи кад је већ ту пут и шупље испод неба [...]. (Ћоп.)

(4) Василије омјери пажљиво тројицу пролетера (нема шта, прилично обучени, утегнути, ту је и оружје, момчине и по!) [...]. (Ћоп.)

(5) Не кажем за онај утисак, тако чест, када се човек тек упознаје, да је то већ старо познанство. Ту је само утисак а познанство у ствари још не постоји. (П.)

\footnotetext{
${ }^{18}$ Прилог $m y$ је у овом случају употребљен у придевској, атрибутској функцији $(m y=\partial о м а ћ)$.

${ }^{19}$ Да то присуство може бити и начелно, а не само конкретно, показује одличан пример који наводи Ашић (2015: 122): Павле је ту/*овде, али је изамао да донесе сунђер. Прилог овде, очигледно, има конкретније значење.
} 
Исту такву употребу прилог ту има и у изразу шта je - my je, са значењем „треба се помирити с оним што је неизбежно; што је учињено, учињено" (PMC):

(6) Дијете једнако држи у памети што му је отац казао да не меље у воденици ђе нађе ћоса, али сад већ помисли: што је, ту је; па рече ћосу [...].(Анm.)

Бити ту може значити и „бити код куће”, будући да је кућа уобичајено место на којем се човек налази (пр. 7), а може значити и „бити где треба, где се очекује, где је (било) предвиђено" (пр.):

(7) Гудиш у пустој кући. Они чији хлеб ждереш нису ту. Можда се неће ни вратити. (Ћос.)

(8) Кочијаш нагло заустави коње, окрену се њему и смешкајући се рече: - Ty смо! (hoc. $)^{20}$

Одатле и узвично Ty смо!, којим Г реагује на битан тренутак откривања чињеница током разговора (пр. 9) или развоја догађаја (пр. 10); прилог ту тада упућује на „место” на линији развоја разговора или догађаја:

(9) ЂОКА: Пре ћу погинути но што ћу дозволити!

КАПЕТАН: Аха! Аха! Ту смо! Нагазили смо на жуљ! (Н.)

(10) Охо, опет је почело некакво необично кошкање између дједа и самарџије! Дај да се прикучим ближе да ми штогод не измакне. Ево, већ се помињу и коњски табани, ту смо. (Ћоп.)

Ако су особе у питању, израз бити ту може значити „позван да нешто уради” (пр. 11), „на услузи/располагању” (пр. 12). Значење „спреман, приправан” може важити и за особе (пр. 13) и за ствари (пр. 14): ${ }^{21}$

(11) Па и онда не знам шта ће им [девојкама, да читају и пишу]. Да читају ваљда из „Кувара” како се праве пуслице и мушкацоне. Ту је муж, па ако му се једу пуслице, а он нека прочита жени како се праве. (Н.)

(12) $[\mathrm{A}]$ ко господину конзулу не би на време стигли државни новци [...], ту је ето он, Саломон Атијас, увек на службу Француском царском... то јест краљевском конзулату и господину конзулу лично, и на располагању са оно мало што има и што може. (А.)

(13) У једном светлом и топлом углу [...] две конзуловице су селе да измењају безбројне речи и лепа осећања. И за једно и за друго ту је била Ана Марија, јер су њена речитост и њена осећајност просто укочиле госпођу Давил. (А.)

\footnotetext{
${ }^{20}$ Сличан је, и врло речит, пример који даје Кордић (2003: 88): „Ту смо”-мукло је рекао Јеап и запалио иигарету. „Ја не кужим стари”- добацио је Michel жмигајући косим очима - ,,што ћемо ми заправо овдје... [...]”. Ауторка коментарише: „Замјена прилога ту помоћу овдје није могућа јер би се умјесто 'стигли смо гдје смо хтјели' добило 'ми се налазимо на овом мјесту' (стр. 88), али то објашњава тиме што „мјесто на које прилог ту упућује није наглашено” (стр. 87).

${ }^{21}$ Сличну, мада не и сасвим исту интерпретацију израза бити ту има и Ашић $(2015,2019)$.
} 
(14) Над нама разгорено небо најављује близину најтајанственијег путника, мјесеца. Ха, ту су грабље, само га закачимо и повучемо, ево га зачас у крилу. (Ћоп.)

6.2. Од значења постојања на актуелном месту развија се и значење постојања у садашњем тренутку. Наиме, пошто је ентитет апстрактан, недоступан чулу вида (сnасење), од значења „овде и сада” остало је само значење „сада":

(15) Исти курир [...] предао је и фон Митереру декрет о његовом премештају из Травника и стављању на располагање Министарству војном. - Ту је било дакле то спасење које пуковник са породицом очекује већ годинама. И сада, кад је било ту, изгледало је врло једноставно, разумљиво само по себи [...]. (А.)

\section{7. Катафоричко my}

Прилог ту може бити употребљен и катафорички - онда кад је корелатив месне клаузе која за њим следи. Чини се, међутим, да то није употреба која се може објаснити на јединствен начин, него су случајеви различити, и већ објашњени у вези са другим употребама. $T y$, наиме, може бити употребљено и егзофорички (пр. 1); може место означено месном клаузом стављати у простор С-ове пажње (пр. 2); може значити „близу”, при чему је деиктички центар неки елеменат ситуације, а не С (у пр. 3 то је свак, у пр. 4 стегно):

(1) Ама, ето ту, чини ми се, неке труловине, као од дрвета... ту где коњ копа! (Кликовац 2019: М. Глишић).

(2) Свитало је, у слеђеном блату, ту где су сада Коларчев универзитет и Капетан-Мишино здање ... (Кликовац 2019: С. Велмар Јанковић)

(3) Планине су постајале непроходне и људи теже покретни и мање предузимљиви. Свак се спрема да презими ту где се затекао [...]. (А.)

(4) $[. .$.$] и ударао се од немоћног гнева дланом по свиленом минтану, ту$ негде где треба да му је стегно. (А.)

\section{8. Изрази ту и тамо, ту и ту}

8.1. Израз ту и тамо, који своју ефектност дугује и алитерацији, може да значи „овде-онде, местимично, понегде” (пр. 1), „понекад” (пр. 2), па и „помало” (пр. 3) (в. Кликовац 2018).

(1) Силазио је у Конзулат, иако је морао да прође кроз разбеснеле гомиле или поред стратишта која су ницала час ту час тамо. (А.)

(2) А чини се, канда се ни непријатељ није боље снашао, па је ту и тамо кокао своје камараде, све док се нису почеле дизати руке на предају. (Ћоп.) 
(3) Идем на Брач. [...] Да, идем да радим, знаш, али онако ту и тамо и да се одморим. (Кликовац 2018: Разг.)

8.2. За израз mу и ту у РМС каже се да „показује место које говорно лице неће да помене, али које мора да буде одређено". Међутим, битно је истаћи - што РМС чини у вези с изразима maj u maj, maд(a) и maд(a) и др. - и да је тад у питању сажето препричавање; при томе је то место било експлицитно наведено у тексту који се препричава, али за само препричавање није битно:

(4) [...] него иди к цару и ишти лађу и у њој триста акова вина и триста акова ракије и уз то још двадесет дунђера, па кад дођеш на лађи ту и ту између две планине, загради воду што је онде, па успи у њу све вино и ракију. (Ант.)

(5) Кад је дете било уједно госпођа М. га је, природно, одвела код лекара, а лекар је савесно превио рану и саветовао да дете, за сваки случај, прими вакцину против беснила. За вакцину треба отићи ту и ту. (ЕК: Политика, 2001)

\section{9. Закључак}

9.1. Прилог mу има врло широку семантику. Најпре, иако најчешће упућује на место на којем се нешто налази одн. на којем се нека ситуација одвија, може упућивати и на правац одн. место завршетка кретања.

Друго, с обзиром на граматичку категорију лица, има следеће употребе.

1) Како би се на основу његовог корена и очекивало, он је 2. лица, у том смислу што Г њиме упућује на место близу C-a, одн. на место на којем се $\mathrm{C}$ налази. У том случају ту је комплементарно са овде.

Од тог упућивања у физичком простору употребе се гранају у два крака: a) преко читавог континуума случајева до прагматичке вредности прекора, кад више нема уопште месно значење нити функцију прилошке одредбе (која је за њега типична), и б) у метафоричке просторе поседовања и намене/пажње/релевантности.

2) Како је то такође уобичајено за заменичке речи 2. лица, mу може бити употребљено и анафорички; штавише, та употреба је и најчешћа и најразуђенија. Најпре, може анафорички упућивати на неки физички ентитет. Најчешће

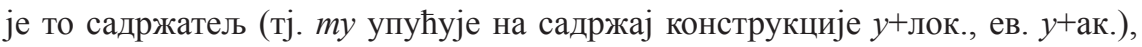
али може бити и носитељ (на+лок., ев. на+ак.) или место одређено другим предлошко-падежним конструкцијама. Апстрактни антецеденти најчешће су управо метафорички садржатељи: околности; писани текст одн. књига; човеков емоционални простор, временски одсечак, област знања и сл.; ентитет који се интерпретира. Осим тога, антецедент може бити и неко циљано стање ствари или активност (mу значи ,ради тога”); неки појам или стање ствари, кад my има врло опште значење „у вези с тим”, или просто само упућује на претходно поменуту ситуацију, при чему се веза између две ситуације мора реконструисати из контекста. Посебно треба поменути анафоричко ту које 
упућује на временски појам, кад је синонимично са тад(a), у значењу „у том тренутку, на том месту у развоју догађаја” или пак „том приликом”.

3) Прилогом ту Г може упућивати и на место у свом простору; $m y$, онда, често има вредност прилога овде/овамо. Могло би се рећи да се та употреба може надовезати на његову основну употребу: оно што је близу С-у истовремено је и на извесној удаљености, али не великој, и од Г-а. Тако ту од заменичке речи 2. лица постаје и заменичка реч 1. лица. Ty тада значи „близу мени” - „мени надохват руке”, „преда мном”, „у мом видном пољу”, „у мојој ближој околини" и сл. Одатле и метафоричко проширење у простор времена: „близу у будућности” и „у блиској прошлости”. Ту може значити и „близу у простору поређења", кад има вредност прилога отприлике.

У оквиру овог значења ту чак може изгубити своју заменичку природу и постати прилог као што су близу, доле, назад и сл. - кад није везано за учеснике у комуникацији, него означава близину било ком ентитету (одн. 3. лицу).

4) На крају, ту може упућивати и на заједнички Г-ов и С-ов простор.

Посебно смо издвојили употребу прилога $m y$ у изразу бити (ев. налазиmu ce) my, у смислу „постојати у датој ситуацији”, „бити присутан”, са различитим конкретизацијама - „код куће”, „где је предвиђено, планирано, где се очекује”; за особе - „позван да нешто уради”, „на располагању”; за особе и ствари - „спреман”. Одатле и метафоричко проширење у простор времена, кад бити ту значи „постојати у овом тренутку”.

9.2. Пошто прилог ту покрива не само простор 2. него делимично и 1. лица, рекли бисмо да одговарајући део подсистема заменичких прилога за место изгледа овако:22

\begin{tabular}{|l|l|l|}
\hline \multirow{2}{*}{} & \multicolumn{2}{|c|}{ Заменички прилози... } \\
\cline { 2 - 3 } & $\begin{array}{l}\text {..3а место на којем се нешто на- } \\
\text { лази/одвија }\end{array}$ & $\begin{array}{l}\text {..3а место које је правац или мес- } \\
\text { то завршетка кретања }\end{array}$ \\
\hline За 1. лице & овде/ту & овамо/ту \\
\hline За 2. лице & \multicolumn{2}{|c|}{ ту } \\
\hline За 3. лице & тамо (онде) & тамо (онамо) \\
\hline
\end{tabular}

У простору 1. лица очигледно влада гужва: у њему се налазе и овде/ овамо и ту - понекад као сасвим синонимични, понекад међусобно незаменљиви. Исход тих конкурентних односа тешко је, наравно, предвидети; али пошто ту покрива велики број значења (па и она која надилазе дату табелу), вероватно је да ће се његов семантички опсег и даље ширити.

9.3. Малочас наведена табела крије у себи, заправо, две. Наиме, у свом основном значењу - кад је 2. лица - прилог ту заузима средишње место у трочланом (и троличном) систему овде - mу - тамо/онде (ако упућује на

\footnotetext{
${ }^{22}$ Овог пута занемарујемо околност што се овде и онде врло често употребљавају и у значењу „овамо” одн. „онамо”. Дешава се и обрнуто, али знатно ређе.
} 
МН), односно овамо - ту - тамо/онамо (ако упућује на МЗК). Међутим, кад је 1. лица, систем више није трочлан, него двочлан: деиктички центар за употребу прилога ту више није C, него Г - који, онда, упућује на место близу себе (прилозима овде/овамо или ту) или далеко од себе (прилозима тамо или, знатно ређе, онде/онамо). Другим речима, заменички прилог ту је место где се систем заменичких речи колеба између трочланог и двочланог:

\begin{tabular}{|l|l|l|}
\hline & \multicolumn{1}{|c|}{ МН } & \multicolumn{1}{c|}{ МЗК } \\
\hline Трочлани систем & овде - ту - тамо/онде & овамо - ту - тамо/онамо \\
\hline Двочлани систем & овде/ту - тамо/онде & овамо/ту - тамо/онамо \\
\hline
\end{tabular}

Такво стање у овом делу система заменичких речи можда наговештава и правац даљег развоја тог система. Али да би се о томе нешто више могло рећи, потребно је утврдити да ли таква колебања постоје и на другим местима у њему и колико су интензивна.

\section{ЛИТЕРАТУРА}

Ашић 2015: T. Ašić, Spatial deictic expression in Serbian ovde, tamo, tu; a new approach, y: Љ. Поповић, Д. Војводић, М. Номаћи (ур.), У простору лингвистичке славистике, Београд: Филолошки факултет, 111-134.

Ашић 2019: Т. Ашић, О апстрактним употребама заменичких прилога овде и ту, Јужнословенски филолог, LXXV/1, 63-71.

Клајн 2005: I. Klajn, Gramatika srpskog jezika, Beograd: Zavod za udžbenike i nastavna sredstva.

Кликовац ${ }^{2}$ 2006: D. Klikovac, Semantika predloga, Beograd: Filološki fakultet, 2006.

Кликовац 2010: Д. Кликовац, Неколико речи о заменицама у српском језику: предлог класификације и одговарајуће терминологије, Научни састанак слависта у Вукове дане, 39/3, 73-84.

Кликовац 2013: Д. Кликовац, Граматичка категорија лица код показних речи у српском језику, Зборник Матище српске за славистику, 83, 269-286.

Кликовац 2016: Д. Кликовац, О употреби показних речи ево, ето и ено, $\mathrm{Ha}$ учни састанак слависта у Вукове дане, 45/3, 101-134.

Кликовац 2017: Д. Кликовац, О употреби заменичких прилога за време онда и тад(a), y: Р. Драгићевић (ур.), Путевима речи - Зборник радова у част Даринки Гортан Премк, Београд: Филолошки факултет, 495-516.

Кликовац 2018: Д. Кликовац, О систему заменичких прилога за место у српском језику: прилог тамо, $y$ : Српска славистика - колективна монографија (Радови српске делегаџије на XVI међународном конгресу слависта), Том I: Језик, Београд: Савез славистичких друштава Србије, $125-140$. 
Кликовац 2019: Д. Кликовац, Српски језик у светлу когнитивне лингвистике, Београд: Друштво за српски језик и књижевност Србије.

Кликовац (у штампи): О показним заменицама оволики, толики, онолики (семантички, синтаксички и прагматички аспект).

Кордић 2002: S. Kordić, Riječi na granici punoznačnosti, Zagreb: Hrvatska sveučilišna naklada.

Кордић 2003: S. Kordić, Prilozi ovd(j)e / tu / tamo / onamo / ovuda / tuda / onuda, Јужнословенски филолог, 59, 81-103.

Пипер 1988: П. Пипер, Заменички прилози у српскохрватском, руском и пољском језику (семантичка студија), Београд: Институт за српскохрватски језик.

Пипер/ Клајн 22014: П. Пипер, И. Клајн, Нормативна граматика српског језика, Нови Сад: Матица српска.

Расулић 2004: K. Rasulić, Jezik i prostorno iskustvo - Konceptualizacija vertikalne dimenzije u engleskom i srpskohrvatskom jeziku, Beograd: Filološki fakultet.

Расулић/Кликовац 2014: К. Расулић, Д. Кликовац (ур.), Језик и сазнағе - Хрестоматија из когнитивне лингвистике, Београд: Филолошки факултет.

Савић/Половина 1989: S. Savić, V. Polovina, Razgovorni srpskohrvatski jezik, Novi Sad: Institut za južnoslovenske jezike Filozofskog fakulteta u Novom Sadu.

Duška B. Klikovac

\section{ON THE USAGE OF THE ADVERB TU AND ON THE NATURE OF THE SYSTEM OF PRONOUN ADVERBS OF PLACE IN SERBIAN}

\section{Summary}

This paper, based on the theoretical framework of cognitive linguistics, explores the usage of the Serbian pronoun adverb $t u$ 'there $e_{\text {PROXIMAL }}$ '. The analysis reveals that $t u$ can be used to point to a place close to the addressee (as can be expected on the basis of its root $t$-, in which case it is complementary to the adverbs ovde 'here' and ovamo 'here, hither'), to a place close to the speaker (in which case it is often interchangeable with the adverbs ovde and ovamo), or to a place in the shared speaker-addressee space. Apart from spatial deixis, $t u$ is also used to point anaphorically in discourse, which in fact turns out to be its most common and most ramified usage. Besides, pointing in the physical space further extends to pointing in abstract, metaphorical spaces. On the basis of these findings, the related subsystem of pronoun adverbs of place in Serbian is reconstructed, whereby it is established that the pertinent subsystem wavers between (i) a three-member (and three-person) variant: ovde - tu - tamo

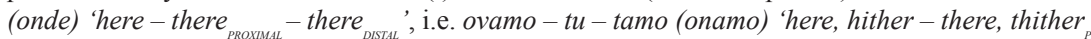
- there, thither $r_{\text {DITIL }}$ ', and (ii) a two-member variant: ovde/tu - tamo (onde) 'here/there

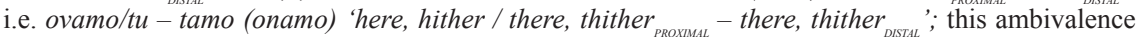
may be indicative of the future direction of the development of the system of pronominal words in Serbian. The analysis also shows that the adverb $t u$ may lose its deictic function altogether (in cases when its deictic centre no longer involves the interlocutors), acquiring the character of adverbs such as blizu 'near', gore 'up', napred 'forward' etc.

Keywords: contemporary Serbian, cognitive linguistics, pronoun adverbs, adverb $t u$, grammatical category of person, exophora, anaphora, conceptual metaphor. 